\title{
The scale and scope of Cretaceous refertilisation of the Kaapvaal lithospheric mantle, Kaapvaal Craton, South Africa
}

\author{
A. F. Kobussen, W. L. Griffin, and S. Y. O'Reilly \\ GEMOC ARC National Key Centre, Dept. Earth \& Planetary Sciences, Macquarie University NSW 2109, Australia
}

\section{Introduction}

There are more than 1000 known kimberlite occurrences scattered throughout southern Africa. These kimberlites can be divided into Group I and Group II, on the basis of their $\mathrm{Pb}, \mathrm{Sr}$, and $\mathrm{Nd}$ isotopic ratios (Smith, 1983). The vast majority of these kimberlites were emplaced during the Jurassic and Cretaceous Periods. Within this subset, there is a firm relationship between group and age of intrusion: Group II kimberlites were emplaced between $\sim 150$ and 115 $\mathrm{Ma}$ and Group I kimberlites were emplaced between $\sim 105$ and 70 Ma (Smith et al., 1985, 1994). Many of these kimberlites carry peridotitic garnet xenocrysts. Major- and trace-element analysis of these xenocrysts yields a wealth of geochemical information about the underlying sub-continental lithospheric mantle (SCLM), including paleogeotherms and several geochemical indicators of depletion or metasomatism. The wide distribution of kimberlites hosting garnet xenocrysts allows the mapping of geochemical parameters over a broader area than usually possible. In addition, the difference in age between Group II and Group I kimberlites allows the comparison of the same volume of SCLM during different intervals of the Jurassic-Cretaceous intrusive episode in areas where these kimberlites overlap spatially.

\section{Methods}

We have obtained major- and trace-element analyses of 14,480 peridotitic garnets hosted in 34 Group II kimberlites and 29 Group I kimberlites (Fig.1). The kimberlites occur in environments both on and off craton. For each suite of garnet xenocrysts from a particular kimberlite, we constructed a paleogeotherm based on the Ni-in-garnet thermometer and $\mathrm{Cr}$ solubility barometer (Ryan et al., 1996). At the depth where garnets very low in $\mathrm{Y}$ become scarce, we introduce a point of inflection and run the deeper part of the geotherm parallel to the diamond-graphite stability line (O'Reilly and Griffin, 2006), similar to geotherms derived from xenolith suites in southern Africa (Finnerty and Boyd, 1987). Once the geotherm is established, all garnets are forced onto the geotherm based on their Ni temperature.

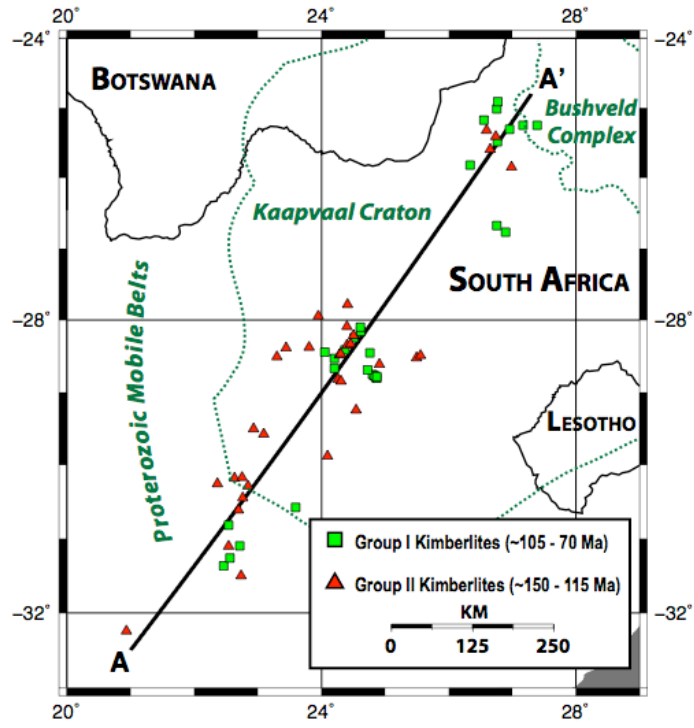

Figure 1. Location map for kimberlites and traverse line. Major tectonic units are outlined in dark green.

Assuming the kimberlites sample the mantle vertically, we have created a cross-section spanning the craton and its southwest margin (A-A'; Fig. 1). Each garnet data point is projected onto the cross-section at its interpreted depth. All kimberlites used are within $100 \mathrm{~km}$ surface distance of the cross-section. Then, using the spline method of Smith and Wessel (1990), we contour the Ti contents, the $\mathrm{Zr}$ contents, the $\mathrm{Zr}-\mathrm{Y}$ ratio, and $\mathrm{X}_{\mathrm{Mg}}$ of olivine co-existing with the garnets along the cross-section using a framework similar to that of Kobussen et al. (2008). We chose to use these four geochemical parameters because they are sensitive indicators of depletion and different styles of metasomatism in cratonic peridotites.

\section{Results}

For each geochemical parameter imaged, we have created two plots. The upper panels for each figure are constructed using garnets hosted in Group II kimberlites and thus sample the mantle between 150$115 \mathrm{Ma}$. The lower panels in each figure are constructed using garnets hosted in Group I kimberlites, which sample the same mantle region later $(<105 \mathrm{Ma})$ during the same intrusive episode. Individual garnets are shown on each plot as open black symbols where they project onto the crosssection, enabling the visual recognition of where plot 
resolution is poor. All sections have $2 \mathrm{x}$ vertical exaggeration.

The $\mathrm{Ti}$ content in garnet ranges from nearly zero to $>6000 \mathrm{ppm}\left(1 \% \mathrm{wt}\right.$. $\left.\mathrm{TiO}_{2}\right)$. Typical values for $\mathrm{Ti}$ in garnet in cratonic peridotites range from 1250 to $2500 \mathrm{ppm}$. Values less than $1250 \mathrm{ppm}$ are considered extremely depleted and values higher than $2500 \mathrm{ppm}$ indicate metasomatism. Figure 2 compares the Ti value in garnets from Group II and Group I kimberlites.

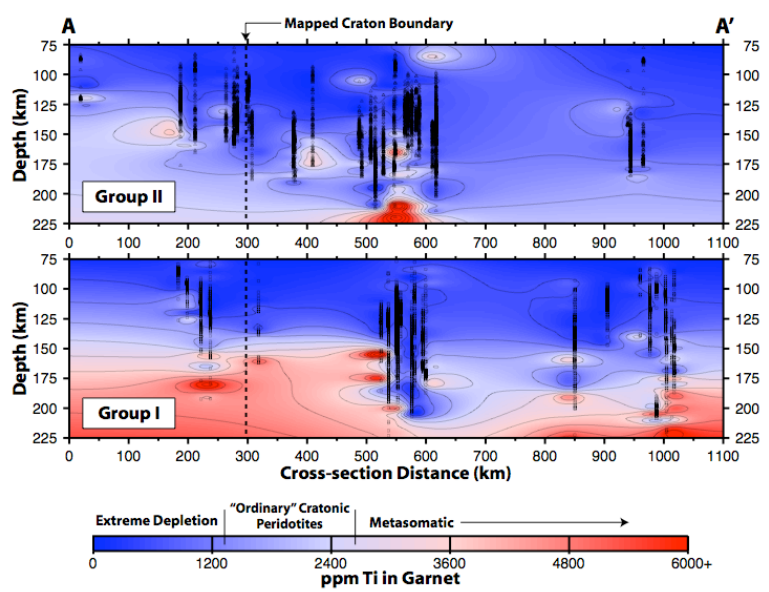

Figure 2. Contoured $\mathrm{Ti}$ contents in garnet hosted in Group II (top panel) and Group I kimberlites (bottom panel) along cross-section A-A' from Figure 1.

In the shallower parts of both sections the garnets have Ti contents typical of cratonic peridotites, or much more commonly with extremely depleted signatures. Garnets from the lowermost parts of the lithosphere, in contrast, show signatures typical of strongly melt metasomatised peridotites and such garnets are more common in Group I kimberlites.

The southwest part of the section ( 0 to 500 $\mathrm{km}$ ) displays a huge enrichment in $\mathrm{Ti}$ between the emplacements of the Group II and Group I kimberlites. The $\mathrm{Ti}$ content of the lithospheric mantle in the Kimberley area ( $\sim 500$ to $600 \mathrm{~km})$ is nearly unchanged during this time. It is unclear how much change there is in the northeast because of sampling patterns, but there appears to be some enrichment in $\mathrm{Ti}$ in the later (Group I) time slice.

The $\mathrm{Zr}$ contents of garnets show a different pattern of depletion/metasomatism (Fig. 3). Again, the shallower parts of both sections show a depleted signature, but the depth extent of depletion is much less and more irregular than for Ti. Particularly noticeable is the large $\mathrm{Zr}$ enrichment in the Kimberley area $(\sim 500-$ $600 \mathrm{~km}$ along section), which can be related to the "phlogopite style" metasomatism commonly observed in xenoliths from the Kimberley area (e.g. Grégoire et al., 2002).

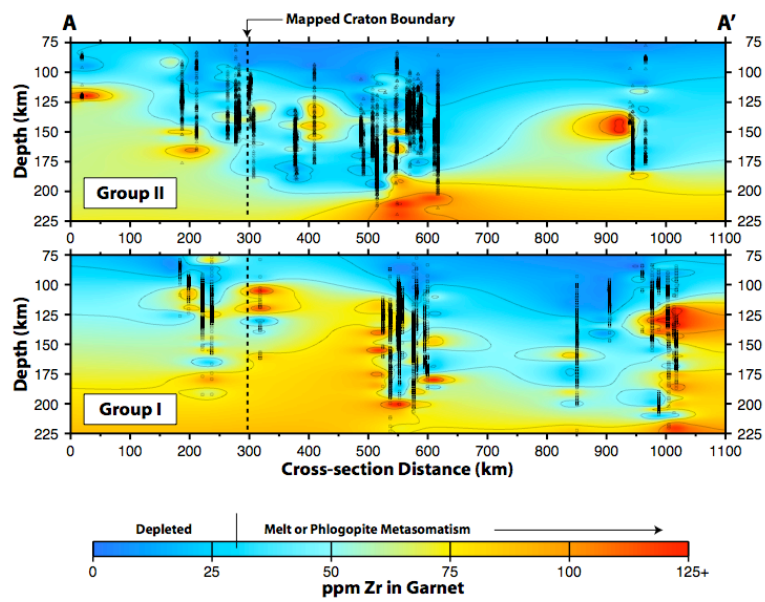

Figure 3. Zr contents of garnet plotted as in Fig. 2.

Another indicator of phlogopite-style metasomatism is the $\mathrm{Zr}-\mathrm{Y}$ ratio measured in garnets (Griffin et al., 2002; Fig. 4). High ratios suggest either phlogopite metasomatism or enrichment related to extreme melt metasomatism. The overlap of high $\mathrm{Zr}$ values (Fig. 3) with high $\mathrm{Zr}-\mathrm{Y}$ ratios (Fig. 4) in the Kimberley area during Group I time indicates phlogopite metasomatism. The phlogopite signature is not observed in the southwest part of the section where there is strong enrichment in Ti between the intrusion of Group II and Group I kimberlites (Fig. 2).

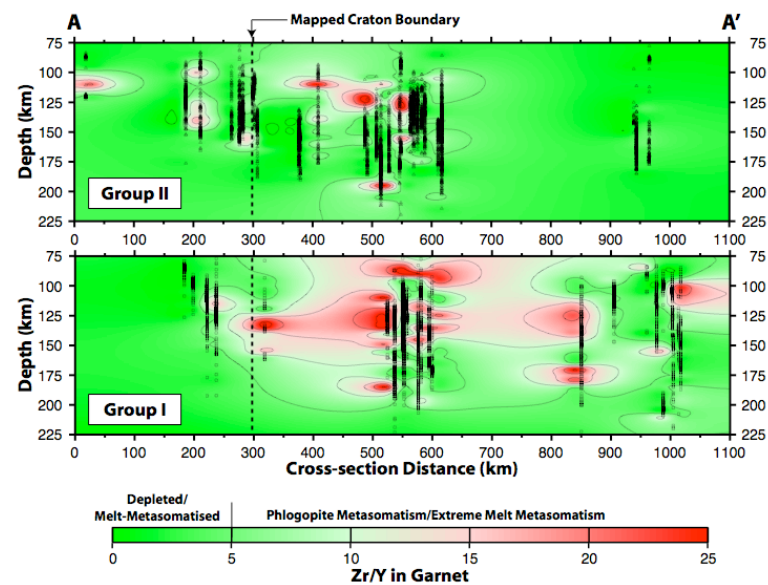

Figure 4. Measured $\mathrm{Zr}-\mathrm{Y}$ ratio in garnets plotted as in Figure 2.

Finally, the $X_{\mathrm{Mg}}$ of olivine coexisting with the garnets was calculated using the method of Gaul et al. (2000; Fig. 5). The pattern of $\mathrm{X}_{\mathrm{Mg}}$ of olivine more closely resembles the pattern observed for Ti than for $\mathrm{Zr}$, but there are important differences. In the NE part of both Group II and Group I sections there is considerable $\mathrm{Fe}$ enrichment compared with the other shallow parts of the sections. This is not accompanied by a rise in $\mathrm{Ti}$. 


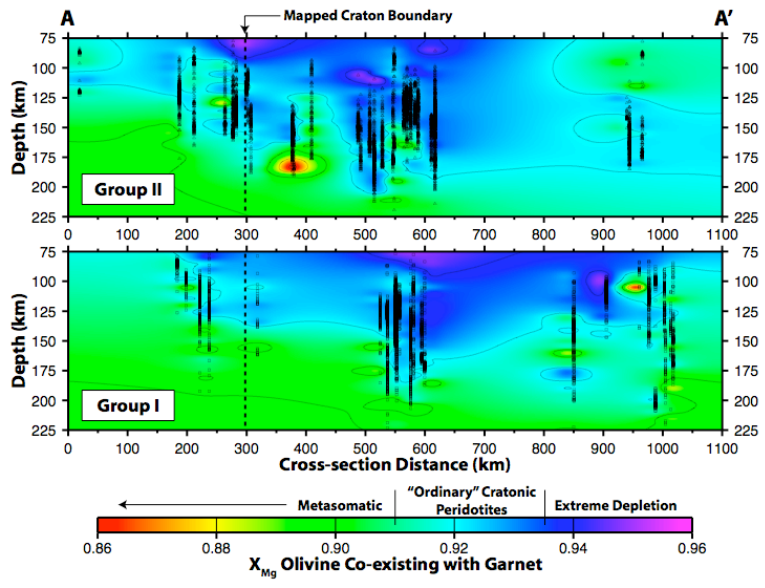

Figure 5. Calculated $\mathrm{X}_{\mathrm{Mg}}$ for olivine coexisting with garnet, plotted as in Figure 2.

\section{Discussion}

Previous work on the Kaapvaal Craton using compilations of data from xenoliths/xenocrysts hosted in Group II and Group I kimberlites have indicated that there was a change in both geotherm and lithosphere chemistry between the eruption of the two groups (Griffin et al., 2003). This conclusion was supported and defined in a spatial context using garnet xenocrysts hosted in kimberlites from the Prieska cluster by Kobussen et al. (2008). In that study, we found a significant change in lithosphere chemistry as defined by $\mathrm{Ti}$ in garnet and the calculated $X_{\mathrm{Mg}}$ of coexisting olivine in a short and well-defined time window of 9 m.y. between the eruption of the Group II and Group I kimberlites.

Here we confirm this conclusion, but find that the change in lithosphere chemistry appears to be more complex than previously proposed. In the Kimberley area, the changes observed between the eruption of the Group II and Group I kimberlites are dominated by phlogopite-style metasomatism in which garnets are enriched in $\mathrm{Zr}$, but not in $\mathrm{Ti}$ and $\mathrm{Y}$.

Melt-related metasomatism is the most likely cause of large-scale modification of the lithosphere in the Prieska area along the SW part of the section (Gurney and Harte, 1980; Kobussen et al., 2008). Bell et al. (2003) suggest that silicate melts might more easily be able to penetrate and metasomatise formerly depleted Proterozoic-age lithosphere due to zones of weakness or melt pathways along tectonic boundaries. This type of infiltration could be assisted by changes in the stress field associated with the opening of the South Atlantic (Bailey, 1992).

\section{Acknowledgements}

We thank De Beers and its staff (especially Dave Apter, Rob Preston, Jock Robie, Simon Shee and Bruce Wyatt) for data, discussions and much assistance.

\section{References}

Bailey, D. K., 1992. Episodic alkaline igneous activity across Africa: Implications for the causes of continental break-up. In Storey, B. C. et al., eds. Magmatism and the causes of continental break-up: Geological Society [London] Special Publication 68, 91-98.

Bell, D. R., Schmitz, M. D., and Janney, P. E., 2003. Mesozoic thermal evolution of the southern African mantle lithosphere. Lithos, 71, 273-287.

Finnerty, A. A., and Boyd, F. R., 1987. Thermobarometry for garnet peridotite xenoliths: A basis for mantle stratigraphy. In Nixon, P. H. ed., Mantle Xenoliths: Chichester, UK, Wiley, p. 381-402.

Gaul, O. F., Griffin, W. L., O’Reilly, S. Y., Pearson, N. J., 2000. Mapping olivine composition in the lithospheric mantle. Earth and Planetary Science Letters, 182, 223-235.

Grégoire, M., Bell, D. R., and le Roux, A. P., 2002. Trace element geochemistry of phlogopite-rich mafic mantle xenoliths: their classification and their relationship to phlogopite-bearing peridotites and kimberlites revisited. Contributions to Mineralogy and Petrology, 142, 603-625.

Griffin, W. L., Fisher, N. I., Friedman, J. H., O’Reilly, S. Y., Ryan, C. G., 2002. Cr-pyrope garnets in the lithospheric mantle 2. Compositional populations and their distribution in time and space. Geochemistry, Geophysics, Geosystems, 3, doi:10.1029/2002GC000298.

Griffin, W. L., O'Reilly, S. Y., Natapov, L. M., and Ryan, C. G., 2003. The evolution of lithospheric mantle beneath the Kalahari Craton and its margins. Lithos, 71, 215-241.

Gurney, J. J., and Harte, B., 1980. Chemical variation in upper mantle nodules from southern African kimberlites. Philosophical Transactions of the Royal Society of London, Series A, 297, 273-293.

Kobussen, A. F., Griffin, W. L., O'Reilly, S. Y., and Shee, S. R., 2008. Ghosts of lithospheres past: Imaging an evolving lithospheric mantle in southern Africa. Geology 36, 515-518.

O'Reilly, S. Y., and Griffin, W. L., 2006. Imaging global chemical and thermal heterogeneity in the subcontinental lithospheric mantle with garnets and xenoliths: Geophysical implications. Tectonophysics, 416, 289-309.

Ryan, C. G., Griffin, W. L., and Pearson, N. J., 1996. Garnet geotherms: Pressure-temperature data from $\mathrm{Cr}$ pyrope garnet xenocrysts in volcanic rocks. Journal of Geophysical Research, 101, 5611-5625.

Smith, C. B., 1983. Pb, Sr and $\mathrm{Nd}$ isotopic evidence for sources of southern African Cretaceous kimberlites. Nature, 304, 51-54.

Smith, C. B., Allsopp, H. L., Kramers, J. D., Hutchinson, G., and Roddick, J. C., 1985. Emplacement ages of Jurassic-Cretaceous South African kimberlites by the $\mathrm{Rb}-\mathrm{Sr}$ method on phlogopite and whole-rock samples. South African Journal of Geology, 88, 249-266.

Smith, C. B., Clark, T. C., Barton, E. S., Bristow, J. W., 1994. Emplacement ages of kimberlite occurrences in the Prieska region, southwest border of the Kaapvaal Craton, South Africa. Chemical Geology, $113,149-169$.

Smith, W. H. F., and Wessel, P., 1990. Gridding with continuous curvature splines in tension. Geophysics, 55, 293-305. 